\title{
THE EFFECT OF THE TEETH PROFILE SHAPE ON POLYMER GEAR PAIR PROPERTIES
}

\author{
Jože Duhovnik, Damijan Zorko, Luka Sedej
}

Original scientific paper

The paper presents an extensive research on two different tooth-flank geometries, i.e. involute and S-gears. A significant difference between the two analyzed geometries was observed during the lifetime testing. The tests were conducted on special test equipment with an axis distance of $20 \mathrm{~mm}$. The material used for the tested gears was POM for the driver gear and PA6 for the driven gear. The same sizes of driver and driven gears were used $(m=1 \mathrm{~mm}, z=20)$. Gears of this size are particularly suitable for micro-gear transmissions. The tests were carried out using different rotational speeds and torques, between $0,8 \mathrm{~N} \cdot \mathrm{m}$ and $1,5 \mathrm{~N} \cdot \mathrm{m}$. During testing the thermal state of the gears was measured with a thermal camera. The stress and deformation analyses of the tested gears were undertaken using numerical simulations employing the finite-element method.

Keywords: failure; involute gears; polymer; S-gears; temperature

Utjecaj oblika profila zuba na svojstva para polimernih zupčanika

Original scientific paper

U radu se predstavlja opsežno istraživanje dviju različitih geometrija boka zuba t.j. evolventnih i S-zupčanika. Zapažena je značajna razlika između te dvije analizirane geometrije tijekom ispitivanja njihovog vijeka trajanja. Ispitivanja su provedena na posebnoj opremi za ispitivanje s udaljenošću vratila od $20 \mathrm{~mm}$. Materijal ispitivanih zupčanika bio je POM za pogonski zupčanik i PA6 za pogonjeni zupčanik. Rabljene su iste veličine pogonskog i pogonjenog zupčanika $(m=1 \mathrm{~mm}, z=20)$. Zupčanici te veličine su naročito pogodni za mikro zupčanični prijenos. Ispitivanja su provedena uz različite brzine vrtnje i okretne momente, između $0,8 \mathrm{~N} \cdot \mathrm{m}$ i $1,5 \mathrm{~N} \cdot \mathrm{m}$. Tijekom ispitivanja toplinskom se kamerom mjerilo toplinsko stanje zupčanika. Analize naprezanja i deformacije ispitivanih zupčanika provedene su numeričkom simulacijom primjenom metode konačnih elemenata.

Ključne riječi: evolventni zupčanici; kvar; polimer; S-zupčanici; temperatura

\section{Introduction}

The use of polymer gears is rapidly increasing due to their advantages compared to gears made from metallic materials. The mass production of plastic gears is cheaper, they carry loads without lubrication, and this makes them extremely attractive for applications where a lubricant is not desirable (e.g., printers, household appliances). Their noise level during operation is significantly lower and they are able to dampen vibrations better. Many of the available polymeric materials allow different variations in terms of material pairs that can be used for the manufacture of gears. To improve the mechanical properties of the materials, various fillers can be added, such as glass and carbon fibres, the positive impacts of which have been recognized [1].

There are no applicable standards yet for the conversion of plastic gears; there are only some recommendations, issued by engineering associations, like VDI 2736 [2] (summarizing the DIN 3990 standard [3]), AGMA 920-A01 [4], ANSI/AGMA 1106-A97 [5], and by individual producers (Kissoft [6], POLYPENCO [7]). There have been comparisons made between different standards and numerical calculations; they revealed significant differences between the calculations based on the recommendations and the numerical results [8]. The VDI 2736 [2] recommendation has collected conversion data for only a few materials. Currently, there are a large variety of possible materials available, which makes the lack of data on these materials a major shortcoming. Other approaches to the dimensioning of plastic gears have been proposed; however, currently they are not yet in general use [9]. Therefore, for the purpose of dimensioning and using plastic gears in real applications, the gears should be tested in operating or similar conditions [8]. Because this testing is time consuming and expensive, researchers are also using accelerated testing, where the moment load of a gear pair is incrementally added $[9,10]$. The goal of such tests is to determine the critical load at which the gear pair fails. Instead of gear testing, research where an attempt was made to simulate the conditions similar to those that occur in the contact of two meshing teeth was also carried out [11]. These studies revealed that simple tribological tests, such as a pin sliding on a disc, cannot predict the wear of polymer gears. There was a correlation found between the gear-testing results and the simulation of a contact with rolling discs; however, the size of the wear varies to a considerable extent [11]. With rolling and relativelysliding discs, the material is always subject to the same load. The meshing gears share the load and the total load is mostly transmitted via two pairs of teeth. For a short period of single-tooth contact the load is transmitted over a single pair of teeth, where the material stress increases proportionally. Finite-element-method simulations showed that at higher loads - due to a large deformation of the teeth - the single-tooth contact period is reduced. Other studies led to similar discoveries [8]. Working on polymer gears with numerical simulations raises the question of how to model the physical properties of the polymer. In order to obtain accurate results it is certainly necessary to take into account the viscoelasticity of the material [12]. Letzelter et al. proposed a numerical model that takes into account the effects of viscoelasticity [12]. This model makes it possible to calculate the load sharing and the transmission error. In the final phase of dimensioning the gears the interest is always in whether a gear under a particular load will achieve the target number of operating cycles. Therefore, research continues in the direction of predicting the lifetime of polymer gears [10] and characterizing the impact parameters that affect the lifetime. 
The advantages of involute gears are well known: a resistance to changes in the centre distance as well as standardised calculation and standardised simple cutting process in the case of metallic materials. However, involute gears also have their shortcomings, i.e., a convex/convex contact along the path of the contact, resulting in higher stress at the contact [13]. If the case of less than a marginal number of teeth, undercutting of the tooth root occurs, thereby weakening the root. Injection moulding allows the creation of special tooth shapes, which are difficult to make using metallic materials. This paper will present testing and a comparison between two different tooth shapes, i.e., involute and S-teeth. S-teeth have a special shape, forming an S-shaped path of contact. The main advantages include a convex/concave contact, which results in lower contact pressures, a higher relative speed, less sliding at the contact, and thus less loss due to friction, and - in the case of lubrication - a thicker oil film. The tooth roots of S-teeth are much wider, compared to the involute teeth, which increases the root strength, while at the same time it means that gears can be created with a much smaller number of teeth, compared to involute gears. The shape of the S-gear's tooth flank is defined using an analytical equation $[13,14$, 15]. A mathematical model allows the shape of the tooth flank and the corresponding counterflank to be defined [14]. The characteristics of S-gears and their advantages were recognised and experimentally confirmed using metal gears $[13 \div 16]$. By varying the parameters that affect the geometry it is possible to obtain a variety of tooth shapes [15]. The centre distance of involute gears can be corrected with a profile shift, while the centre distance of S-gears is uniquely determined by the number of teeth and the module. Profile shifts in S-teeth are not possible [16].

Based on the advantages of S-gears, as presented in the literature, we found it interesting to apply the shape of S-teeth to polymer gears. This paper will present the findings that resulted from a systematic testing of polymer gears with involute and S-teeth. The goal was to determine and compare the load bearing characteristics of both geometries in the case of polymer gears. Such comparisons between two different types of tooth-flank geometry were not found in the literature.

\section{Tested gears data}

We tested two different tooth geometries. Involute gears are the most widely used because they have important advantages over other types. The main advantage and the reason why involute gears are the most widely used lies in the insensitivity of involute-gear pairs to changes in the centre distance [17]. Involute-gear pairs comply with the law of gearing and provide a constant gear ratio, also with different centre distances, which does not apply to other tooth shapes.

Other tooth shapes have also been developed due to some of the weaknesses relating to involute teeth. S-gears can be used both for transmitting large forces, such as wind turbines, and the small forces of micro-drives [14]. At its root, the tooth is thicker with S-gears, compared to the involute gears in an identical module. Due to its known advantages $[13 \div 16]$, the S-tooth geometry seems to be suitable for use with polymer gears. Hlebanja [16] defined the rack tooth flank profile of S-gears by the following equation:

$y_{P i}=a_{P}\left(1-\left(1-x_{P i}\right)^{n}\right)$,

where $\left(x_{P i}, y_{P i}\right)$ are the Cartesian coordinates originating in the kinematic point $\mathrm{C}, a_{P}$ is the size factor and $n$ is the exponent. Both parameters $a_{P}$ and $n$ have influence on the S-gears tooth shape and thereby their expected load bearing characteristics. Variation of S-gear shape and the influence of the main parameters was analysed by Kulovec and Duhovnik [15].

The values that determine the geometry of the tested gears are presented in Tab. 1. The typical differences between both gears are shown in Fig. 1.

Table 1 Tested gears data

\begin{tabular}{|c|c|c|}
\cline { 2 - 3 } \multicolumn{1}{c|}{} & Involute gears & S-gears \\
\hline $\mathrm{m}(\mathrm{mm})$ & 1 & 1 \\
\hline$z$ & 20 & 20 \\
\hline$\alpha\left(^{\circ}\right)$ & 18 & 18 \\
\hline$n$ & - & 1,85 \\
\hline$a_{P}$ & - & 1,66 \\
\hline$b(\mathrm{~mm})$ & 6 & 6 \\
\hline
\end{tabular}

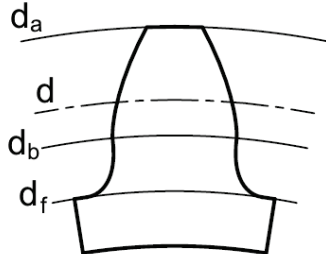

a)

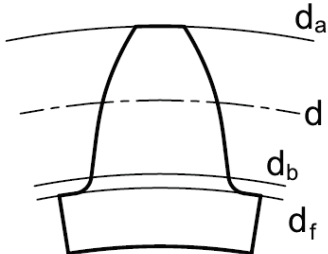

b)
Figure 1 Characteristic differences between: a) involute tooth shape and b) S-gears tooth shape

The tested gears were injection moulded. It is a known fact that for pairing polymer gears that run without lubrication it is better to use different materials for the driver and the driven gear. Due to adhesion, the friction between two identical materials increases, causing excessive wear. The POM/PA6 combination has proved to be a suitable material pair according to research results found in the literature [18]. According to the results in the reference [18], a gear pair with a POM driver gear lasted much longer than a PA6 driver gear. For this reason we decided to use POM for the driver gear (Delrin 500P NC010 manufactured by DuPont), while the driven gear material was PA6 (Ultramid B3S manufactured by BASF). As our objective was to determine the effect of tooth-flank geometry on the lifetime, it was necessary to build the gears as accurately as possible. In terms of tolerance checks, our tested gears belonged to tolerance classes between 7 and 8 [19].

\section{Analysis of shrinkage deviations}

All the tested gears were injection moulded. The injection-moulding parameters for both of the used materials are presented in Tab. 2.

The injection moulding of polymer gears requires taking account of the material shrinkage during the 
cooling down. In the initial tool-design phase it is possible to predict this shrinkage by means of simulation tools. Nowadays, they fairly accurately predict a material's behaviour. The results of the injectionmoulding simulations are shown in Fig. 2 and Fig. 3. Based on the shrinkage estimations, it is vital to make a mould so much bigger that the gear will have the desired shape after it has cooled down. In order to manufacture gears with higher tolerance classes $(Q<8$ [19]), special attention should be paid to the tooth flank, as the shrinkage at the tip of the tooth is smaller than at the root. The shape of the polymer gear's tooth flank after cooling down deviates from the theoretical shape, defined by the analytical involute or S-tooth equation [14]. Therefore, by means of iterations, it is necessary to correct the tool and find the optimum injection parameters in order to achieve the smallest possible deflections. In our case, the injection parameters were set according to previous experiences and were optimized through a process of trial and error. Another method to find the optimum injection parameters is the method called Design of Experiments, the application of which is presented in $[20,21]$. Injection simulations for both teeth geometries were performed with the Autodesk Simulation Moldflow Insight 2015 software. The simulation results showed that the shrinkage deviations vary along the tooth's height and thickness. The size of the analysed tooth shrinkage mostly depends on the chosen material and the injection parameters. Different sizes of shrinkage deviations along the gear's thickness affect the meshing conditions, as the load is not on the whole flank area at the beginning. In order to characterize the effect of the shrinkage along the gear thickness, tooth contact-pattern checking needs to be performed. Running along the entire gear rim, a diaphragm gate was used for the gear injection. The diaphragm gate was also modelled in the injectionmoulding simulation (Fig. 2).

Table 2 Injection-moulding parameters

\begin{tabular}{|l|c|c|}
\hline \multicolumn{1}{|c|}{ Injection moulding parameter } & PA6 & POM \\
\hline Injection moulding pressure $(\mathrm{MPa})$ & 60 & 80 \\
\hline Tool temperature $\left({ }^{\circ} \mathrm{C}\right)$ & 70 & 50 \\
\hline Nozzle temperature $\left({ }^{\circ} \mathrm{C}\right)$ & 248 & 205 \\
\hline Injection moulding time $(\mathrm{s})$ & 0,8 & 0,8 \\
\hline Packing pressure $(\mathrm{MPa})$ & $60-40-20$ & $80-60-40$ \\
\hline Packing pressure time $(\mathrm{s})$ & 3 & 3 \\
\hline Cooling $(\mathrm{s})$ & 14 & 20 \\
\hline
\end{tabular}

A numerical simulation was performed using the mean values and does not take account of the crystallization and polymerization occurring in the teeth and the gear body. A gear begins to cool down at the top of the tooth, where crystallization occurs, while in the tooth root - where the temperature is higher polymerization takes place. Fig. 3 shows an approximate view of the estimated shrinkage deviations along a tooth's height - on the side of the tooth with the diaphragm gate. The transparent colour shows the tool into which the gear was injected, while the dark colour shows the cooled tooth. Comparing the shrinkage estimations in Fig. 3 shows that they are different, depending on the material used. It was observed that the shrinkage primarily affects the diameters of the tip and foot circles. They were smaller after the cooling down (Tab. 3). Along the tooth thickness the shrinkage deviation is smaller by one size class, because a single tooth contains less material, which in turn means less shrinkage. Consequently, shrinkage also affects the diameter of the kinematic circle, which affects the gear pair's centre distance.
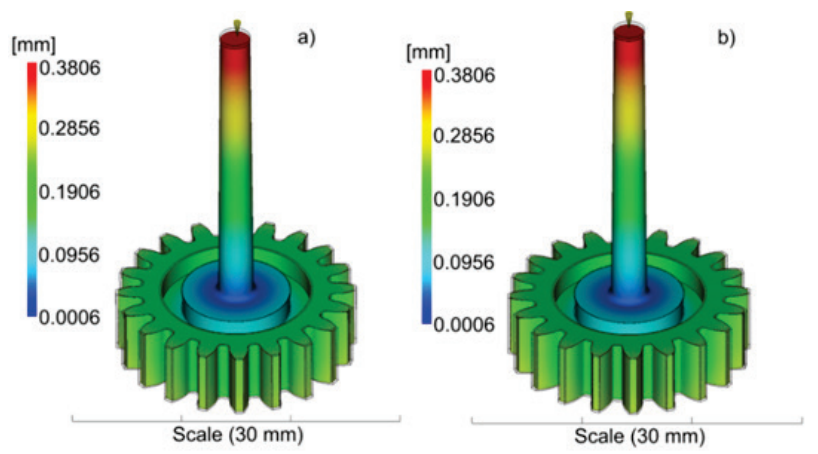

Figure 2 PA6 material shrinkage according to a numerical simulation: a) involute gear, b) S-gear

With gear-body shrinkage being the key element for defining a new geometry after injection moulding, only this shrinkage is taken into consideration for the initial approximation. The effect of shrinkage on tooth thickness, and the difference between crystallization and polymerization, should be taken into account when specifying the accuracy of the teeth under $Q=8$.

Table 3 The effect of shrinkage on the reduction of the gear-tip diameter

\begin{tabular}{|c|c|c|c|}
\hline Material & $\begin{array}{c}\text { Gear } \\
\text { geometry }\end{array}$ & $\begin{array}{c}\text { Rack-profile-tip } \\
\text { diameter }(\mathrm{mm})\end{array}$ & $\begin{array}{c}\text { Gear-tip diameter } \\
\text { after cooling }(\mathrm{mm})\end{array}$ \\
\hline PA6 & involute & 22 & 21,52 \\
\hline PA6 & S & 22 & 21,51 \\
\hline POM & involute & 22 & 21,55 \\
\hline POM & S & 22 & 21,55 \\
\hline
\end{tabular}

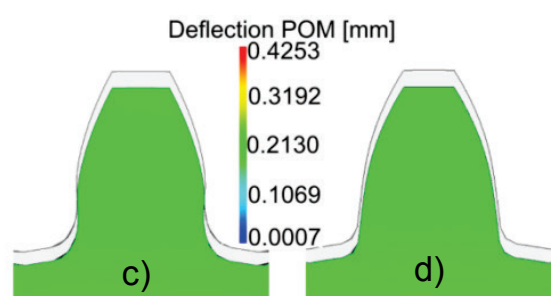

b)

C)

d)

Figure 3 Estimated shrinkage deviations along the height of a tooth: a) involute gear - PA6, b) S-gear- PA6, c) involute gear - POM, d) S-gear - POM

\section{Test device}

A special test device was designed for the purpose of testing the gears (Fig. 4). Its design allowed free access to the gears for the purpose of temperature measurement with a thermographic camera. The test device allows a continuous torque setting by using drive and braking electric motors (EMs), controlled via frequency 
regulators. For the drive and braking EMs, two Siemens 4-pole asynchronous electric motors with a nominal torque of $2,5 \mathrm{~N} \cdot \mathrm{m}$ were used. The power is transmitted from the drive motor to the gear drive shaft via a toothed belt, which has a beneficial impact on the dampening vibrations. The gear ratio of the belt transmission is $i=$ 0,7 , which means a theoretical maximum torque on the drive gear shaft of $1,75 \mathrm{~N} \cdot \mathrm{m}$.

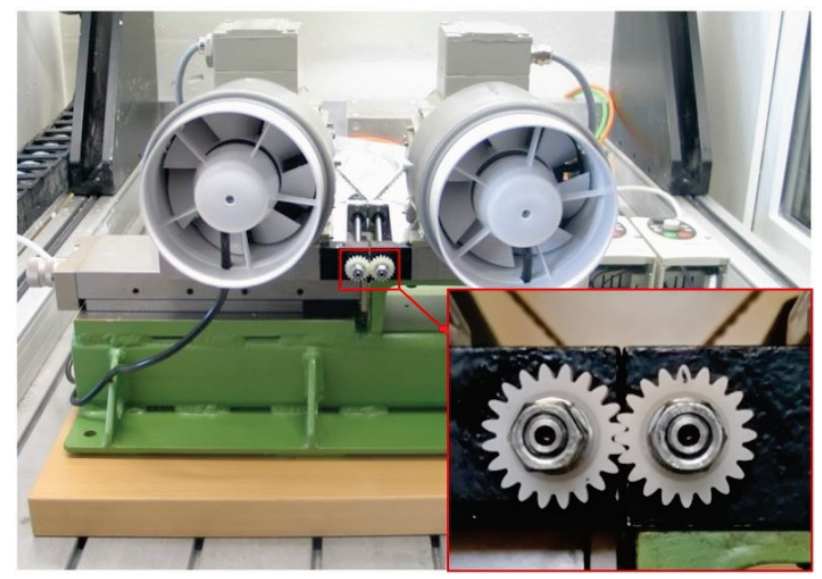

Figure 4 Test device

\section{$5 \quad$ Testing conditions}

The tests were carried out at room temperature and humidity. All the gear pairs were running without lubrication. The values of the coefficient of friction for the analysed material pair POM/PA6 in non-lubricated conditions range between 0,18 [2] and 0,29 [10], depending on the source. Lifetime of tested gears was determined for moment loads from 0,8 to $1,5 \mathrm{~N} \cdot \mathrm{m}$. Each gear pair was tested at constant moment load and constant rotational speed. At each moment load at least five tests were done (except 0,8 and $0,9 \mathrm{~N} \cdot \mathrm{m}$ ). It is a known fact that various types of defects occur for different rotational speeds and moment loads $[1,22]$. This is also presented in chapter 7 . The tests were carried out until failure or for a certain number $\left(10^{7}\right)$ of operational cycles, which is a common criterion in the case of metallic gears. During the tests the temperature was measured on the gear surface, using a thermographic ThermaCam FLIR T420 camera with a capture frequency of $60 \mathrm{~Hz}$. When measuring the gear's surface temperature, it is vital to measure it during operation, not when the gears have stopped, as the temperature drops quickly [18]. In addition, the position of the thermal camera is vital for measuring the temperature during operation. If positioned above the gears, it cannot measure an accurate temperature due to the turbulent disturbances caused by meshing gears [23]. However, positioning the camera at an angle can cause changes in the emissivity, which can also affect a measurement made with a thermal camera [23]. A special design of the testing device makes it possible to align the camera with the gear's rotational axis (Fig. 4). The temperature on the surface of the gear consists of three parts: the ambient, the bulk and the flash temperature [9]. The thermal camera's measurement point was positioned at the teeth contact. The flash temperature is short lived and cannot be measured with our measuring apparatus. As a result, what we measured was basically the tooth-body temperature (i.e., the bulk temperature). An emissivity of $\varepsilon=0,8$ was set for both materials.

\section{$6 \quad$ Lifetime test results}

The involute and S-gear pairs were tested under operating conditions. The tests were carried out at two different regulator frequencies, i.e., $25 \mathrm{~Hz}$ and $35 \mathrm{~Hz}$ which control the output of the electric motors. The involute teeth were tested at both frequencies, while the S-teeth were only tested at the higher frequency of $35 \mathrm{~Hz}$, as their lifetime is expected to be longer. The regulator frequency determines the rotational speed at particular moment load. Involute and S-gears that were tested at regulator frequency $35 \mathrm{~Hz}$ and same moment load, were thereby also tested at same rotational speed. In that way the lifetime results of both geometries are comparable. The results of the involute-teeth testing for the frequency regulator set at $25 \mathrm{~Hz}$ (lower rotational speeds) are shown in Fig. 5. The target number of operational cycles $\left(2 \times 10^{6}\right.$ cycles) was achieved by the gears that were subject to moments of $1 \mathrm{Nm}, 1.1 \mathrm{Nm}$ in $1.2 \mathrm{Nm}$. The Wöhler curve is drawn for a $50 \%$ probability of failure. The involute gears that were tested at higher rotational speeds $(35 \mathrm{~Hz})$ achieved $2 \times 10^{6}$ operational cycles at moments of $1 \mathrm{Nm}$ and $1,1 \mathrm{~N} \cdot \mathrm{m}$. The gears under identical moment loads lasted for a smaller number of cycles due to the higher frequency of the load i.e. higher rotational speed. The generated temperatures for a higher frequency of the load are considerably higher. For example, the temperature of a gear that is loaded with a moment of $1 \mathrm{Nm}$ and $973 \mathrm{rpm}$, rises from $37{ }^{\circ} \mathrm{C}$ to $50{ }^{\circ} \mathrm{C}$ at a rotational speed of 1405 $\mathrm{rpm}$. With the mechanical properties of polymer materials depending on the temperature, it is impossible to think about identical stress conditions in a material, regardless of there being an identical moment load in both cases. It was observed that the distribution of test-item failures is considerably higher at a higher rotational speed.

Contrary to expectations, the S-gears achieved a shorter lifetime (Fig. 5). The gears heated up during operation, and due to thermal expansion the entire gearing system expands slightly. Like with shrinkage, the expansion is not even along the tooth height. The literature [23] states that a change in the centre distance and, consequently, a change in the lateral backlash, significantly affects the lifetime of the gears. From this we can conclude that an error in the centre distance affects the lifetime of polymer S-gears, due to the changed kinematics of meshing. Because of the change in flank geometry and centre distance the law of gearing is no longer fulfilled. Comparing the Wöhler S-gear and the involute-gear curves reveals that they intersect. The trend curve indicates that at higher moments the S-gear should last for a larger number of operational cycles. However, at the tested rotational speed they did not reach the area of lasting dynamic strength, so it would make sense to continue the research in the direction of higher moment loads and lower rotational speeds. In principle, the ordinate axis in the Wöhler curve's coordinate system should include the stress; however, we deliberately replaced the stress with the moment loads at which the gears were tested. Analytical methods (VDI 2736 [2]) as well as numerical calculations define the stress conditions 
for a particular constant module of elasticity, usually specified at room temperature. Because the gears heat up during operation, it is not possible to claim that the stress within a material is identical to the stress calculated in an analytical (VDI 2736 [2]) or numerical way, as the impact of the viscoelasticity is neglected in both cases.

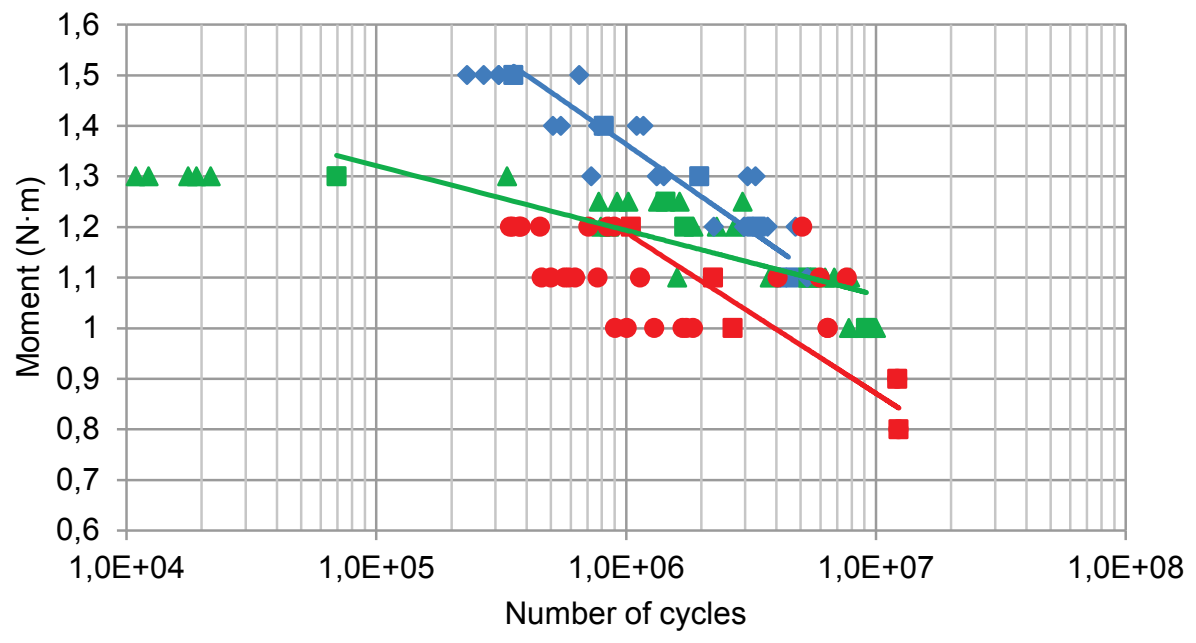

Figure 5 Comparing the results of all lifetime tests:

involute gear failure $(25 \mathrm{~Hz}), \quad 50 \%$ probability of involute gear failure $(25 \mathrm{~Hz})$, — Wöhler curve for involute gear $(25 \mathrm{~Hz})$ - involute gear failure $(35 \mathrm{~Hz}), \quad 50 \%$ probability of involute gear failure $(35 \mathrm{~Hz})$, - Wöhler curve for involute gear $(35 \mathrm{~Hz})$; - S-gear failure $(35 \mathrm{~Hz}), \mathbf{0} 50 \%$ probability of involute S-gear failure $(35 \mathrm{~Hz}), \quad$ Wöhler curve for S-gear $(35 \mathrm{~Hz})$

\section{Types of defects}

Different moment loads cause different types of defects in polymer gears [1]. Polymer gears tend to fail in two typical ways: due to fatigue (cracked flank surface and fractures in the root), and due to material softening [10]. For the moment loads at which the gears were tested, temperature-induced defects were expected. Three different types of defects occurred at the tested loads. These defects included: a broken tooth due to root fracture; plastic tooth deformation, coupled with a broken tooth; and plastic tooth deformation (Tab. 4). All three types are shown in Fig. 6. An increased moment load increases both the contact stress between the tooth flanks and the tooth deformation, followed by an increased temperature as a result of friction and hysteresis effects [12]. Hysteresis is a consequence of internal friction in the material which occurs by large deflections of teeth. When a polymer material heats up beyond the temperature of the glass transition, the material softens, causing severe plastic deformation of the teeth and a gear pair can no longer work properly.

Table 4 Types of defects that occurred under specific operating conditions

\begin{tabular}{|c|c|c|c|}
\hline Moment $(\mathrm{N} \cdot \mathrm{m})$ & Rotational speed $(\mathrm{rpm})$ & Gear type & Type of defect \\
\hline 1 & 973 & involute & broken tooth at the root \\
\hline 1,1 & 962 & involute & broken tooth at the root \\
\hline 1,2 & 948 & involute & plastic deformation, broken tooth \\
\hline 1,3 & 930 & involute & plastic deformation, broken tooth \\
\hline 1,4 & 912 & involute & plastic deformation, broken tooth \\
\hline 1,5 & 884 & involute & plastic teeth deformation \\
\hline 1 & 1405 & involute & plastic deformation, broken tooth \\
\hline 1,1 & 1390 & involute & plastic deformation, broken tooth \\
\hline 1,2 & 1376 & involute & plastic teeth deformation \\
\hline 1,3 & 1362 & involute & plastic teeth deformation \\
\hline 0,8 & 1424 & $\mathrm{~S}$ & visible fracture at the root \\
\hline 0,9 & 1417 & $\mathrm{~S}$ & visible fracture at the root \\
\hline 1 & 1405 & $\mathrm{~S}$ & broken tooth at the root \\
\hline 1,1 & 1390 & $\mathrm{~S}$ & plastic teeth deformation, broken tooth \\
\hline 1,2 & 1376 & $\mathrm{~S}$ & plastic teeth deformation, broken tooth \\
\hline 1,3 & 1362 & $\mathrm{~S}$ & plastic teeth deformation \\
\hline
\end{tabular}
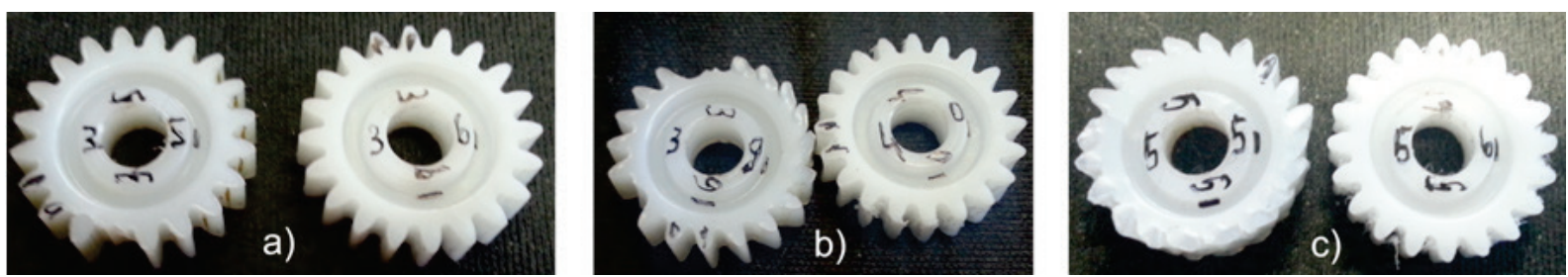

Figure 6 Types of defects that occurred during the tests: a) broken tooth at the root, b) broken tooth at the root and plastic tooth deformation due to softened material, c) plastic tooth deformation due to softened material 


\section{Stress analysis}

When analysing gears, it is vital to be familiar with the stress conditions that occur in the material at given loads. For the tested loads of the involute gears, the stress in the root and the tooth flank (Tab. 5) was calculated according to the VDI 2736 [2] recommendations. The stress according to VDI 2736 [2] was calculated for the involute gears only, since the recommendation only defines the conversion for this geometry.

The stress in the S-gears was calculated using numerical simulations, performed with the Ansys Workbench 15.0 software. To make a comparison with the stresses, calculated according to VDI 2734 [2], a numerical simulation was also used to calculate the stress in the involute gears. The numerical model was set so that it simulated the meshing along the entire active length of the tooth flank. This makes it possible to calculate the stress that occurs in the root and the flank of the tooth at all the meshing points (Figs. 7 and 8). The highest calculated values for the Misess comparison stress during a single tooth's meshing are presented. In the diagram the stresses are drawn according to the gear's rotation angle. The characteristic meshing points $(\mathrm{A}, \mathrm{B}, \mathrm{C}, \mathrm{D}, \mathrm{E})$ are clearly marked. It was observed that at higher loads the stress in the root and the flank of the tooth lasts longer, i.e., for a larger tooth rotation angle. This leads to the conclusion that at higher loads and, consequently, higher deformations, the tooth-contact period increases. The path of the contact increases at the beginning and the end of the meshing, where the extended path of the contact does not coincide with the theoretical shape of the path of the contact for a particular tooth shape [8]. Comparing the calculated values according to VDI 2736 [2], and the

stresses, calculated using a numerical simulation, it is clear that the stresses obtained in a numerical way are lower than those calculated according to the VDI 2736 [2] recommendation. The largest impact on such a deviation comes from the choice of the value for the factors $K_{\mathrm{F}}$ and $K_{\mathrm{H}}$.

As expected, the calculated stress on the flank was lower for the S-teeth, which is the result of the convex/concave contact (Fig. 8). Calculating the stress on the tooth flank reveals that the peak stresses appear at the beginning and the end of the meshing. It is assumed that they result from an impact shock [6] at the beginning of the meshing. Tip relief helps to minimize the peak stress during the initial shock, which was not performed in the geometry that was analysed in the simulation. Somewhat contrary to expectations, the calculated stresses in the Sgear's root are higher than those in the involute gear's root, regardless of there being a greater thickness in the Sgear's tooth root. It can be concluded that the lower calculated stresses for the involute teeth are due to the impact of rounding in the tooth root. The impact of the rounding radius in the root was analysed in [24], where it was found that the stress in the tooth root is lower in the teeth that have a longer rounding radius.

Table 5 Stress in the involute gear, calculated according to VDI 2736

\begin{tabular}{|c|c|c|}
\hline Load $(\mathrm{N} \cdot \mathrm{m})$ & Root stress $(\mathrm{MPa})$ & Flank stress $(\mathrm{MPa})$ \\
\hline 1 & 68,63 & 81,31 \\
\hline 1,1 & 75,50 & 85,28 \\
\hline 1,2 & 82,36 & 89,08 \\
\hline 1,3 & 89,22 & 92,71 \\
\hline 1,4 & 96,09 & 96,21 \\
\hline 1,5 & 102,95 & 99,59 \\
\hline
\end{tabular}
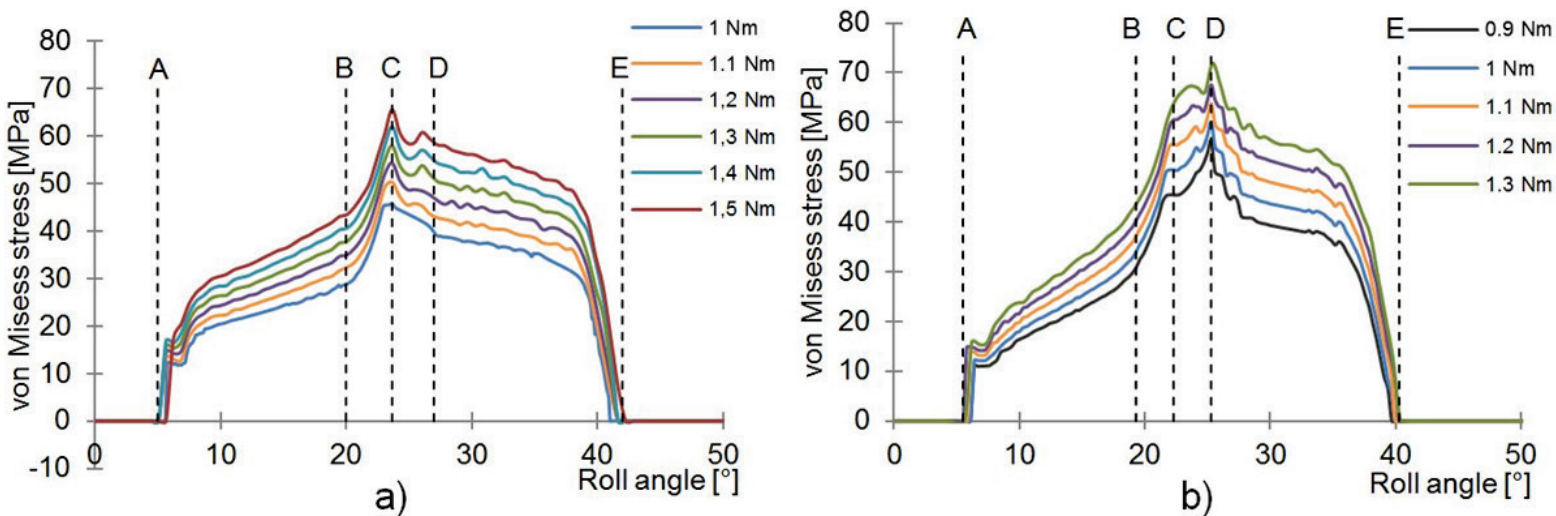

Figure 7 von Mises stresses in the root of the driver gear: a) involute teeth, b) S-teeth
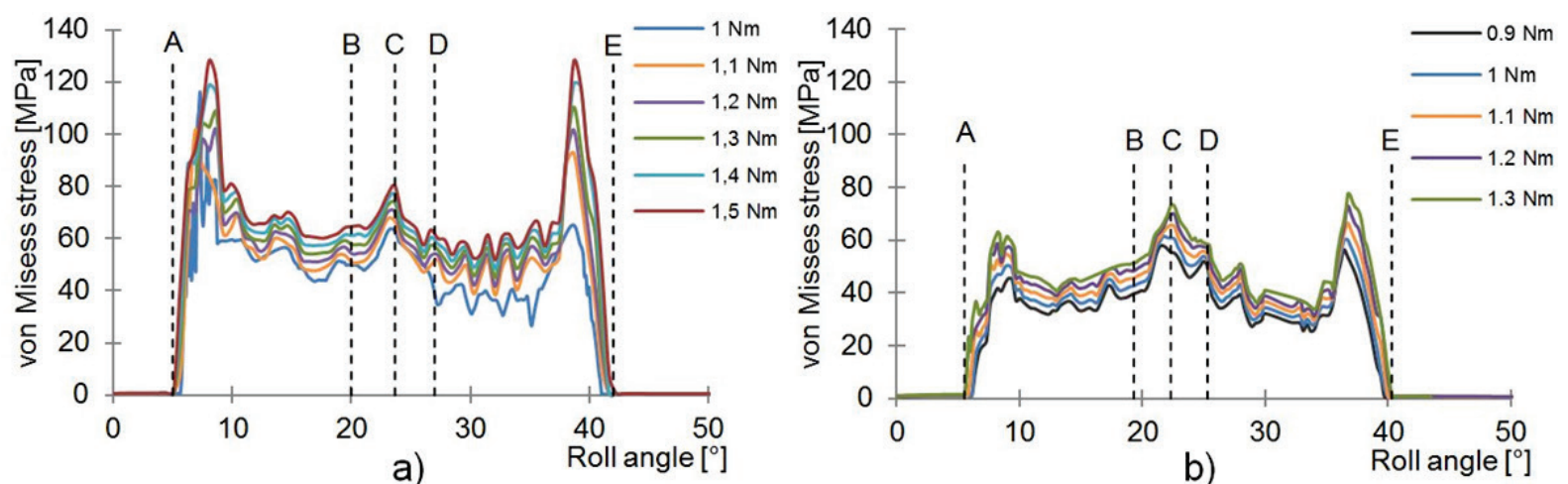

Figure 8 von Mises stresses on the driver tooth flank: a) involute teeth, b) S-teeth 


\section{Deformation analysis}

Transmission error (TE) is one of the criteria that can serve as a basis for predicting tooth deformation. The TE of a meshing gear pair is defined as the difference between the actual rotation of the driven gear (driven shaft) and the theoretical rotation of the driven gear (driven shaft). Theoretically (in ideal conditions), the driver and the driven gears are rigid bodies. The main reasons for transmission errors are geometrical deviations of the gears (eccentricity, centre-distance error, uneven tooth thickness and pitch width) and local tooth deformations. In [25] it was observed that geometrical deviations in polymer gears have a much smaller impact on the transmission error than the tooth deformations.
For our testing purposes, the TE is calculated using a numerical model that takes into account only the impact of tooth deformation. The results of the calculations for the involute teeth are presented in Fig. 9.a, and for S-teeth in Fig. 9.b. Due to the several-size-classes-smaller elastic modulus of polymers, compared to metals, the tooth deformations in polymer gears are incomparably higher.

Based on the calculated TE for both types of tooth, it is clear that it is smaller for the S-teeth (Fig. 10a). This is an indication that the local tooth deformations of the $\mathrm{S}$ teeth are smaller, which is a reasonable expectation for thicker tooth roots. With increasing load, the difference between the calculated TE for both types of teeth decreases (Fig. 10b). The maximum values of the TE for both types of teeth occur in the area of a single tooth contact.
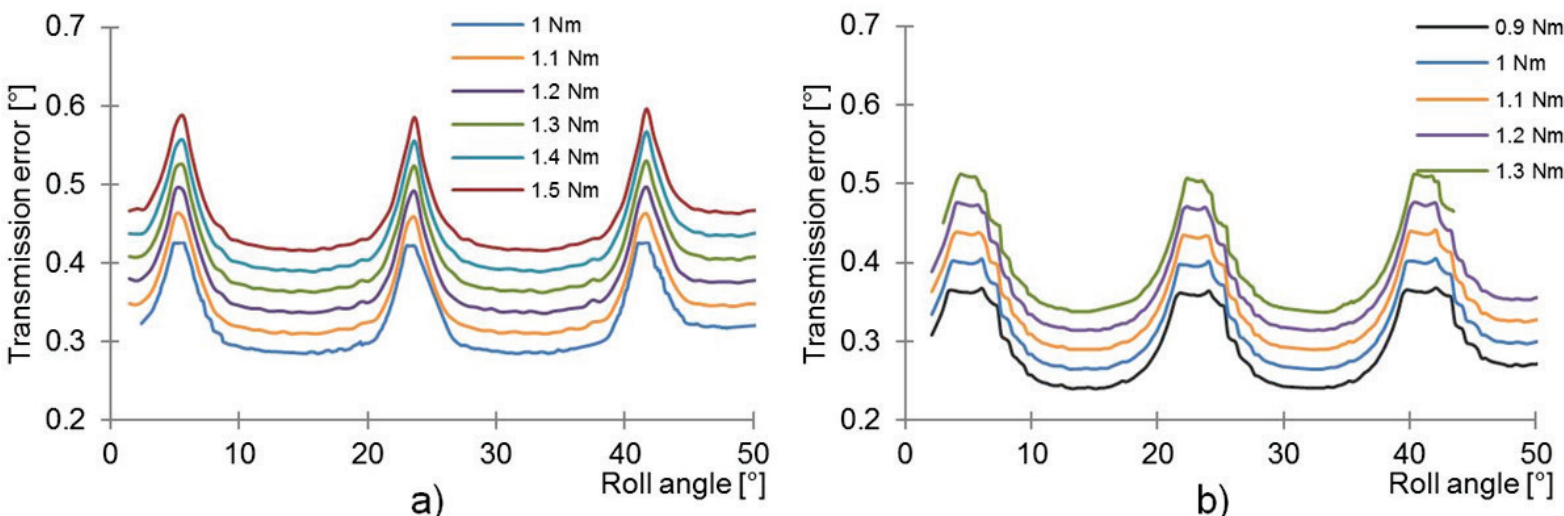

Figure 9 Calculated transmission error of the tested gear pairs: a) involute teeth, b) S-teeth
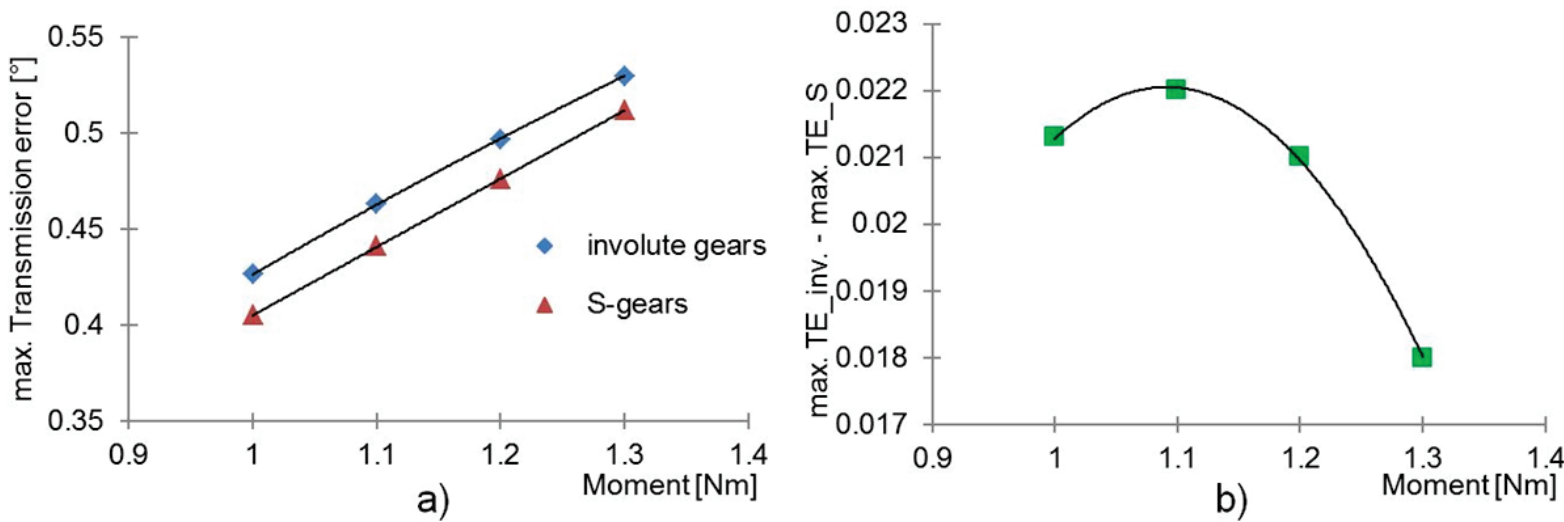

Figure 10 a) Maximum calculated values of TE, b) differences between the highest values of the calculated TE for the involute and S-teeth

The entire load in the area of a single-tooth contact is transferred via a single tooth. As a consequence, it is subject to greater deformation. It is also clear that an increased load increases the difference between the highest and the lowest calculated TE. This was observed in both types of teeth, while the S-teeth are subject to a steeper TE increase. It is assumed that this difference somehow affects the lifetime of the gears.

\section{Temperature measurement}

The surface temperature of the gears was measured for different moments and rotations. The tests were carried out for two rotational speed ranges $(930 \div 973$ rpm and $1362 \div 1401 \mathrm{rpm})$ and moments of $1 \div 1,3 \mathrm{~N} \cdot \mathrm{m}$. Fig. 12 shows the temperature measurement with a thermal camera. The measurement point where the temperature readings were taken is indicated. The gear temperatures for the given loads rise rapidly at the beginning of operations, but after that they flatten out. Fig. 11 shows a comparison between the measured temperatures and those calculated in the tooth root according to the VDI 2736 [2] recommendation. In line with this recommendation, the temperature calculations should follow the Hachmann-Strickle model [26], where in our case two values were used for the heat-transfer coefficient in the tooth root, i.e., $k_{\vartheta, f u \beta}=(1700$ and 2100$)$ $K \cdot(\mathrm{m} / \mathrm{s})^{0,75} \cdot \mathrm{mm}^{1,75}$.

The results, presented in Fig. 11, show that the temperature rises significantly under identical moment loads and a higher rotational speed. The temperature increase results from a higher frequency of the load (more 
tooth contacts) and constant heat dissipation to the surrounding space. Only the temperature of the involute gear pairs' operation was measured. As a reference point for our measurement, a comparison between the measurement and the calculations reported in [10] is also indicated.

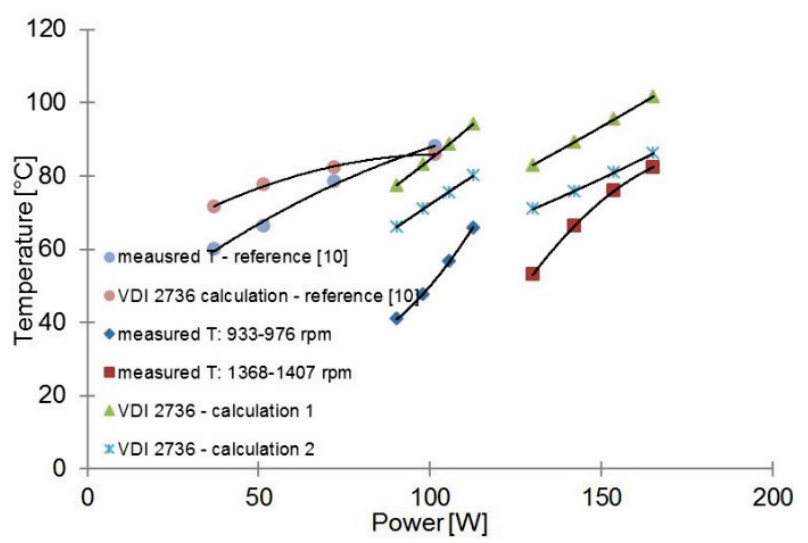

Figure 11 Comparison between the measured and calculated temperatures for different transmitted powers.

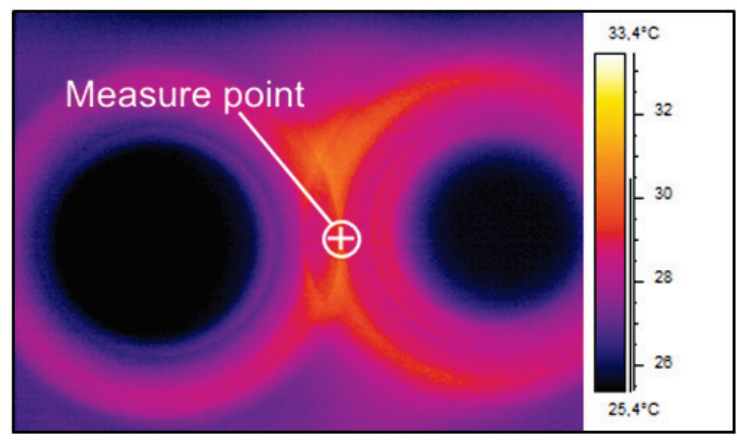

Figure 12 Measurement with thermal camera

\section{Conclusion}

Having tested different types of gears, the focus should be directed towards the accurate manufacturing of gears. As polymer gears are mainly injection moulded, material shrinkage during cooling should be considered during the tool's design. It was observed that shrinkage mostly affects the dimensions of the tip and foot diameters. Given the results of the injection simulations, it can be concluded that the geometry of the tooth flank has no significant impact on the shrinkage. The effect of shrinkage on tooth thickness, should be taken into account when specifying the accuracy of the teeth under $Q=8$.

Involute gears have showed better performance by lifetime testing at lower moments $(1 \div 1,2 \mathrm{~N} \cdot \mathrm{m})$. However, the trend of the curves indicates that the S-gears would last longer at moments exceeding $1,2 \mathrm{~N} \cdot \mathrm{m}$. Based on the test results it can be concluded that S-gears are suitable for applications where higher moment loads are transmitted; however, a large number of operational cycles should not be expected. The error in centre distance affects the kinematics of meshing S-gears.

The lifetime tests revealed that polymer gears fail in different modes. Fatigue defects appear at lower loads, while higher loads cause temperature-induced defects. During the transition, a combination of temperature and fatigue defects occurs, i.e., plastic deformation in combination with tooth fracture.

The analysis of the stress conditions confirmed the advantage of a convex/concave S-gear contact. The calculated stress on the tooth flank was lower than that of the involute gears. It was a little surprising that a higher stress on the tooth root was calculated for the S-teeth, regardless of the greater thickness in the tooth root. The possible reasons were explained.

Local tooth deformation can be suspected from the calculated transmission error, which is the largest in the range of a single tooth contact, when the tooth is subject to the greatest deformation. It was observed that S-gears have a smaller transmission error, thanks to having a greater tooth thickness at the root.

A significant increase in temperature was observed when the rotational speed increased and the moment loads remained the same. A comparison between the calculated temperatures according to the VDI 2736 [2] recommendations and the recorded surface temperatures of the gears was made. For the proposed value of heattransfer coefficient in the tooth root, i.e., $k_{\vartheta, f u \beta}=2100$ $K \cdot(\mathrm{m} / \mathrm{s})^{0,75} \cdot \mathrm{mm}^{1,75}$ measured and calculated values of the surface temperature do not match very well. Further research regarding the calculation of surface temperature should be considered.

\section{References}

[1] Senthilvelan, S.; Gnanamoorthy, R. Damage mechanisms in injection molded unreinforced, glass and carbon reinforced Nylon 66 spur gears. // Applied Composite Materials. 11,6(2004), $\quad$ pp. $377-397 . \quad$ DOI: 10.1023/B:ACMA.0000045313.47841.4e

[2] VDI 2736: Blatt 2, Thermoplastische Zahnräder, Stirngetriebe, Tragfähigkeitsberechnung. VDI Richtlinien. VDI-Verlag GmbH, Dusseldorf, 2014

[3] DIN 3990: Calculation of load capacity of cylindrical gears. German National Standard. Berlin, 1987.

[4] AGMA 920-A01: Materials for Plastic Gears. American Gear Manufacturers Association, 1500 King Street, Suite 201, Alexandria, Virginia 22314, 2001

[5] ANSI/AGMA 1106-A97: Tooth Proportions for Plastic Gears. American Gear Manufacturers Association, 1500 King Street, Suite 201, Alexandria, Virginia 22314, 1997.

[6] Beermann, S. Estimation of lifetime for plastic gears. // Proceedings of AGMA fall meeting / Detroit, 2007, pp. 117.

[7] Polypenco Gear Design. Polypenco Corporation, USA, 1985.

[8] vanMelick, H. G. H. Tooth-bending effects in plastic spur gears. // Geartechnology (September/October 2007). https://www.dsm.com/content/dam/dsm/highperfor mancegears/en_US/documents/Tooth-Bending-effects-inplastic-spur-gears. (6. 3. 2015.).

[9] Mao, K. A new approach for polymer composite gear design. // Wear. 262, 3-4(2007), pp. 432-441. DOI: 10.1016/j.wear.2006.06.005

[10] Pogačnik, A.; Tavčar, J. An accelerated multilevel test and design procedure for polymer gears. // Materials and Design. 65, 1(2015), pp. 961-973. DOI: 10.1016/j.matdes.2014.10.016

[11] Wright, N. A.; Kukureka, S. N. Wear testing and measurement techniques for polymer composite gears. // Wear. 251, 1-12(2001), pp. 1567-1578. DOI: 10.1016/s00431648(01)00793-1 
[12] Letzelter, E.; de Vaujany, J. P.; Chazeau, L.; Guingand, M. Quasi-static load sharing model in the case of Nylon 6/6 cylindrical gears. // Materials and Design. 30, 10(2009), pp. 4360-4368. DOI: 10.1016/j.matdes.2009.04.008

[13] Hlebanja, G.; Kulovec, S.; Hlebanja, J.; Duhovnik, J. Sgears made of polymers. // Ventil. 20, 5(2014), pp. 358366.

[14] Hlebanja, G. Specially shaped spur gears: A step towards use in miniature mechatronic applications. // Balkan Journal of Mechanical Transmissions. 1, 2(2001), pp. 25-31.

[15] Kulovec, S.; Duhovnik, J. Variation of S-gear shape and the influence of the main parameters. // Proceedings of the International Conference on Gears/ Garching, 2013, pp. $1535-1541$.

[16] Hlebanja, J.; Hlebanja, G. Constructive Measures to increase the load-carrying capacity of gears: The characteristics of S-gears. // Machine Design. 1, 1(2008), pp. 33-42.

[17] Norton, R. L. Design of Machinery: An introduction to the synthesis and analysis of mechanisms and machines. 2nd ed. Worcester Polytechnic Institute, Worcester, Massachusetts, 1999.

[18] Mao, K.; Li, W.; Hooke, C. J.; Walton, D. Friction and wear behaviour of acetal and nylon gears. // Wear. 267, 1-4(2009), pp. 639-645.

[19] SIST ISO 1328-1:1999: Cylindrical gears - ISO system of accuracy - Part 1: Definitions and allowable values of deviations relevant to corresponding flanks of gear teeth. Ljubljana, 1999.

[20] Roblek, L.; Tavčar, J. Precise injection moulding of polymer gears. // Ventil. 20, 6(2014), pp. 448-452.

[21] Hakimian, E.; Sulong, A. B. Analysis of warpage and shrinkage properties of injection-molded micro gears polymer composites using numerical simulations assisted by the Taguchi method. // Materials and Design. 42, 1(2012), pp. 62-71. DOI: 10.1016/j.matdes.2012.04.058

[22] Senthilvelan, S.; Gnanamoorthy, R. Effect of rotational speed on the performance of unreinforced and glass fiber reinforced Nylon 6 spur gears. // Materials and Design. 28, 3(2007), pp. 765-772. DOI: 10.1016/j.matdes.2005.12.002

[23] Letzelter, E.; Guingand, M.; de Vaujany, J. P.; Schlosser, P. A new experimental approach for measuring thermal behaviour in the case of nylon $6 / 6$ cylindrical gears. // Polymer testing. 29, 8(2010), pp. 1041-1051. DOI: 10.1016/j.polymertesting.2010.09.002

[24] Senthilvelan, S.; Gnanamoorthy, R. Effect of gear tooth fillet radius on the performance of injection molded Nylon 6/6 gears. // Materials and Design. 27, 8(2006), pp. 632639. DOI: 10.1016/j.matdes.2004.12.015

[25] Meuleman, P. K.; Walton, D.; Dearn, K. D.; Weale, D. J.; Driessen, I. Minimization of transmission errors in highly loaded plastic gear trains. // J. Mechanical Engineering Science,Proceedings of the IMechE Part C/ 2007, pp. 11171129.

[26] Hachmann, H.; Strickle, E. Polyamide als Zahnradwerkstoffe. // Konstruktion im Maschinen - Apparate und Gerätebau. 18, 3(1966), pp. 81-94.

\section{Authors' addresses}

prof. dr. Jože Duhovnik, univ. dipl. iň̆. str.

Faculty of Mechanical Engineering, University of Ljubljana Aškerčeva 6, 1000 Ljubljana, Slovenia

E-mail: joze.duhovnik@lecad.fs.uni-lj.si

\section{Damijan Zorko, mag. in ̌̌s str.}

Faculty of Mechanical Engineering, University of Ljubljana

Aškerčeva 6, 1000 Ljubljana, Slovenia

E-mail: damijan.zorko@lecad.fs.uni-lj.si
Luka Sedej, dipl. inž. str.

Faculty of Mechanical Engineering, University of Ljubljana Aškerčeva 6, 1000 Ljubljana, Slovenia

E-mail: luka.sedej@lecad.fs.uni-lj.si 